\title{
Sustainable Transport System
}

\author{
Jothilakshmy $\mathbf{N}^{1}$, Marudachalam V M ${ }^{2}$ \\ ${ }^{1}$ Research Scholar, School of Architecture and Planning, Anna University, Chennai, India. \\ ${ }^{2}$ Professor, Head of Planning, School of Architecture and Planning, Anna University, Chennai, India. \\ e-mail: jothi.lakshmy@gmail.com
}

\begin{abstract}
This paper deals with the sustainable approach for the main infrastructure of any metropolitan city, transportation. The topic is introduced with the definition of sustainable community, the major issues in sustainable development. How the major environmental threats are tackled and in that Transport sector is dealt in detail. A sustainable transport system is defined and different land use measures contributing to sustainable transport are dealt with and conclusions are drawn out.
\end{abstract}

Key words: Sustainable Development, Sustainable Community, Urban Movement, Sustainable Transport, City Models

\section{DEFINITION OF SUSTAINABLE TRANSPORTATION}

Asustainable transportation system is one that:

D Allows the basic access needs of individuals and societies to be met safely and in a manner consistent with human and ecosystem health, and with equity within and between generations is affordable, operates efficiently, offers choice of transport mode, and supports a vibrant economy.

D Limits emissions and waste within the planet's ability to absorb them, minimizes consumption of non-renewable resources, limits consumption of renewable resources to the sustainable yield level, reuses and recycles its components, and minimizes the use of land and the production of noise.

\section{A SUSTAINABLE WORLD WHERE TRANSPORTATION IS A KEY CONTRIBUTOR}

Sustainable transportation is an aspect of global sustainability, which involves meeting present needs without reducing the ability of future generations to meet their needs.

Sustainability has three components: environment, society, and economy.

Environment refers to the surroundings of humans and other life forms that support them and limit their activity according to basic physical laws. Environmental factors affect present well being and determine most of the legacy we leave our descendants.

Society is a complex of human interactions and how they are organized. Humans have evolved to be mostly dependent on their societies; thus the sustainability of societies is a necessary condition for meeting human needs.

Societal factors are important for sustainability because they determine the present quality of life and because they can be a major component of the legacy to future generations.

Economy describes available resources and how the resources are organized to meet human needs and goals.

Economic factors mostly comprise means of influencing environmental and societal factors.

Transportation of people and goods is among the means used by humans to influence societal and economic factors and to meet their needs and goals.

Transportation can be sustainable on account of the kind of impact it has on environment and society. It can also be a means of helping to achieve sustainability in other aspects of human endeavor.

\section{HOW CAN TRANSPORTATION BECOME MORE SUSTAINABLE?}

\section{A. With respect to society, transportation systems should:}

A) Meet basic human needs for health, comfort, and convenience in ways that do not stress the social fabric.

B) Allow and support development at a human scale, and provide for a reasonable choice of transport modes, types of housing and community, and living styles.

C) Produce no more noise than is acceptable by communities.

D) Be safe for people and their property. 
B. With respect to the economy, transportation systems should:

a) Provide cost-effective service and capacity.

B) Be financially affordable in each generation.

c) Support vibrant, sustainable economic activity.

C. With respect to the environment, transportation systems should:

a) Make use of land in a way that has little or no impact on the integrity of ecosystems.

b) Use sparingly energy sources that are essentially not renewable or inexhaustible.

c) Use other resources that are renewable or inexhaustible, achieved in part through the reuse of items and the recycling of materials used in vehicles and infrastructure.

d) Produce no more emissions and waste than can be accommodated by the planet's restorative ability.

\section{BARRIERS TO SUSTAINABILITY}

There are several barriers to the attainment of sustainable transportation. Four of the most important are these:

a) More than for most other areas of human endeavour, decision-making about transportation by governments, corporations, and individuals has become locked into modes that reinforce the present unsustainable arrangements and trends.

b) There is a mindset that achieving sustainable transportation is too costly, difficult, and will threaten our quality of life and lifestyle.

c) Combustion of low-cost oil provides more than 99 per cent of the energy for motorized transportation and creates many of the environmental problems that result from transportation. Harnessing renewable alternatives will be a major challenge.

d) Mechanisms for identifying improvements in sustainable transportation, and disseminating resulting success stories, and beneficial trends are inadequate.

Overcoming the institutional barriers that prevent good decision-making for transportation may be a greater challenge than overcoming the technological barriers that stand in the way of reducing the use of fossil fuels.

Cities Are Dynamic and full of movement the types of movements occur in Cities are

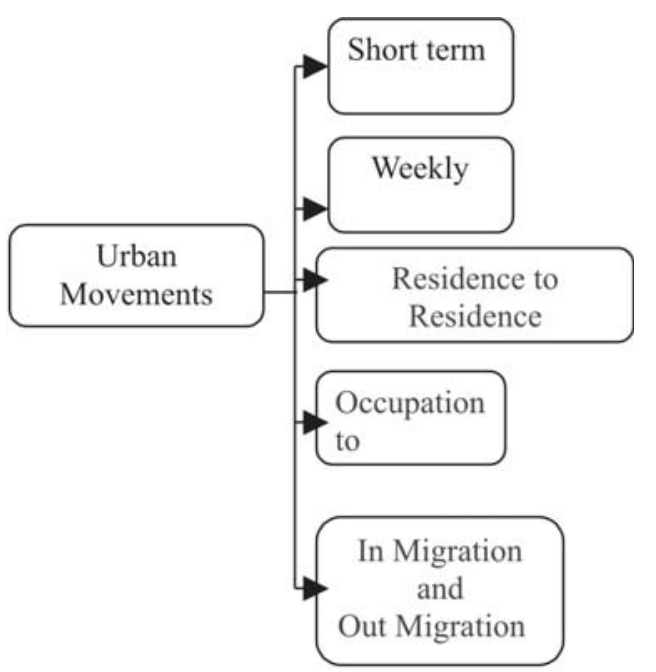

\section{PLANNING AND DESIGN PRINCIPLES}

Walkable community design-800m equating to a 10 minute walk for all day-to-day activities/living.
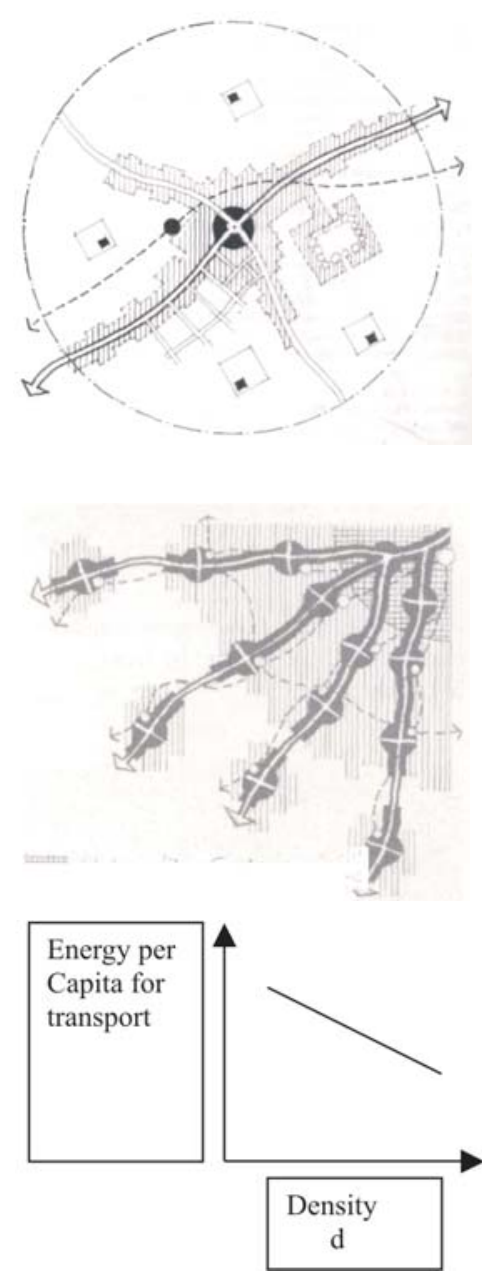
- Community facilities such as schools, health centres and open spaces are distributed around the neighbourhood reflecting more localised catchments and their greater requirements for space.

* The neighbourhood provides a wide range of different housing opportunities not just in terms of dwelling size but also in terms of affordability and tenure.

* This provides the basis for a mixed community representative of society at large rather than having a narrow socialfocus.

* Surrounding streets is a function of the scale and role of a centre, the density of population and the degree of competition from neighbouring centres.

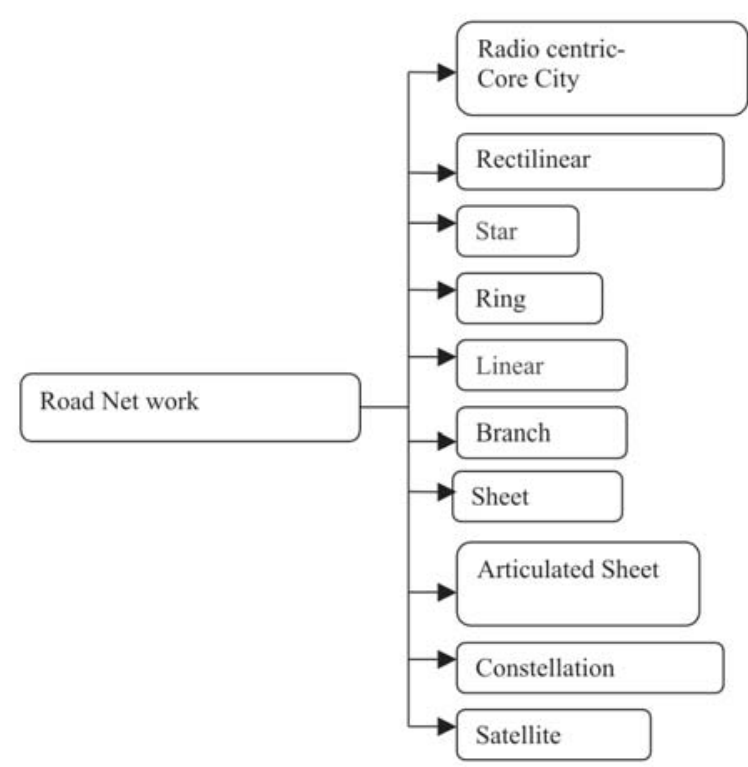

Table : Land Use Measures Contributing To Sustainable Transport

\begin{tabular}{|l|l|l|}
\hline \multicolumn{1}{|c|}{ Land Use Planning Policy } & $\begin{array}{c}\text { Potential Contribution To Sustainable } \\
\text { Transport Policy }\end{array}$ & \multicolumn{1}{|c|}{ Complexities } \\
\hline Compact Cities & Can Reduce Travel Distances & Individuals May Still Prefer Car Use \\
\hline Mixed Use Development & $\begin{array}{l}\text { Can Enable Travel Distances To Be } \\
\text { Reduced }\end{array}$ & $\begin{array}{l}\text { People May Not Actually Live Next } \\
\text { To Their Work }\end{array}$ \\
\hline $\begin{array}{l}\text { Location Of Homes Near } \\
\text { Facilities, \& Vice-Versa } \\
\text { Walk- And- Cycle-Friendly } \\
\text { Development }\end{array}$ & Can Be Located To Minimise Overall Travel & $\begin{array}{l}\text { Individuals May Not Choose To } \\
\text { Use Closest Facilities }\end{array}$ \\
\hline Public Transport & $\begin{array}{l}\text { Locating Homes And Businesses Near To } \\
\text { Public Transport Nodes }\end{array}$ & $\begin{array}{l}\text { Individuals May Still Prefer Car } \\
\text { Use }\end{array}$ \\
\hline $\begin{array}{l}\text { Car-Free Developments } \\
\text { Free Areas And 'Clear Zones' }\end{array}$ & $\begin{array}{l}\text { Can Restrict Car Use And Encourage } \\
\text { Alternatives To The Car }\end{array}$ & $\begin{array}{l}\text { May Simply Shift Traffic Problem } \\
\text { Elsewhere. }\end{array}$ \\
\hline Settlement Size & $\begin{array}{l}\text { A Large Enough Settlement Can Provide } \\
\text { The Critical Mass }\end{array}$ & $\begin{array}{l}\text { The Car May Still Be The Preferred } \\
\text { Mode }\end{array}$ \\
\hline \hline
\end{tabular}

\section{EVALUATION OF THE PERFORMANCE OF CITY MODELS-SUSTAINABILITY CHARACTERISTICS}

The Evaluation of the performance of city models based on agreed sustainability characteristics are done for all the six city models under 15 headings

1. Degree of containment of development

2. Population density relative to land needed

3. Viability of public transport

4. Dispersal of vehicular traffic
5. Viability of mixed uses

6. Access to services and facilities

7. Access to green open spaces

8. Environmental conditions

9. Potential for social mix through variety of housing

10. Potential of local autonomy

11. Potential self sufficiency

12. Degree of adaptability 
13. Imageability of the city as a whole

14. Imageability of parts of the city

VII. CHENNAI- A CASE STUDY

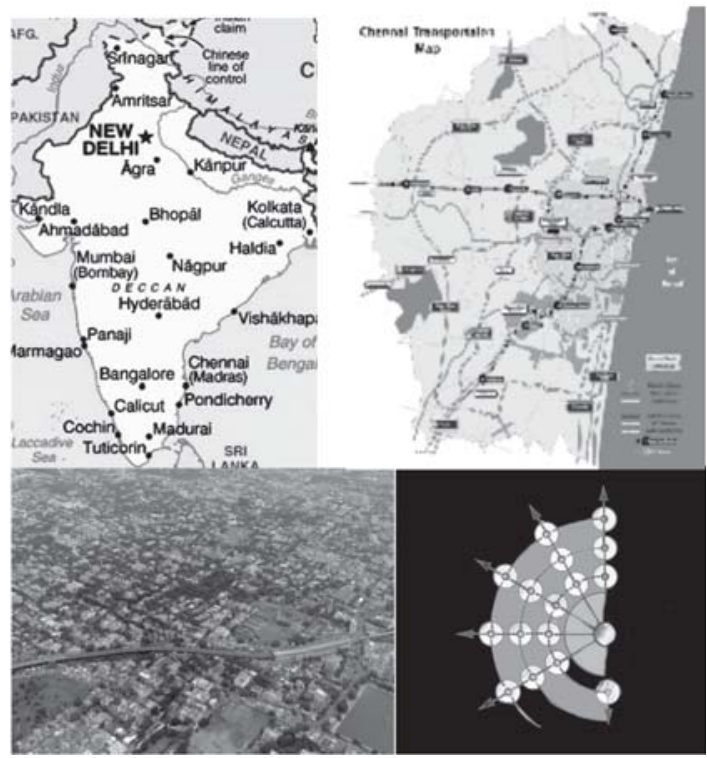

Chennai Major road Network

A study conducted in the major parts of Chennai city on travel mode has revealed the following results.

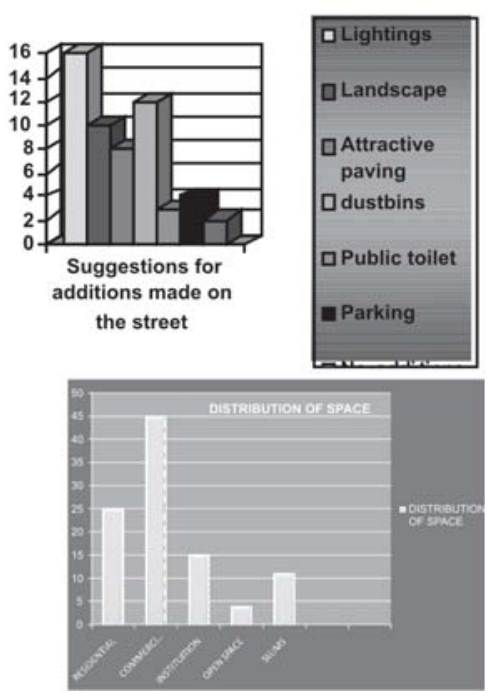

$\checkmark$ Pedestrian pathways should be improved, provided uniform and should be able to be used comfortably by the Physically Challenged also.

$\checkmark$ Provide multi-level car parking.

$\checkmark$ Future buildings should be designed following strict parking requirements.
Create awareness and encourage usage of metro trains.

$\checkmark$ In Chennai the government has planned to operate monorail for $490 \mathrm{~km}$.

$\checkmark$ Construction for the path for monorail will be at least $100 \mathrm{~km}$.

$\checkmark$ Chennai is situated near the sea, so a way can't be dug up for Metro rails, like which was already introduced in Delhi \& Kolkatta, so the government plan to introduce Monorail.

$\checkmark$ Monorail can be installed in short days and the money spent is also low.

$\checkmark$ For Balcony rail it will take Rs.80 to 100 crore for constructing a bridge of $1 \mathrm{~km}$, for Metro rail it will take at least 150 crore to construct the way. But the money to spend for Monorail is just 50crore and it will take small space for constructing the way.

$\checkmark$ In starting they have planed to take 14,000 people from one place to another place, gradually they will increase to 50,000 people.

$\checkmark$ There are examinations to install Monorail in future in Chennai, Hyderabad and Bangalore.

$\checkmark$ Monorails are very safe to travel, zero accidents translates to no system down time, less liability suits and most importantly, No Injuries and Death have registered so far, it will not foot step from the track like trains.

$\checkmark$ Most monorails are electrically powered, and are nonpolluting.

$\checkmark$ Most run on rubber tires and are very quiet.

$\checkmark$ Monorails are the most aesthetically pleasing of all elevated rail systems.

$\checkmark$ Their sleek design blends in with modern urban environments.

$\checkmark$ Quick construction time results in less disruption to the surrounding environments, whether business or residential.

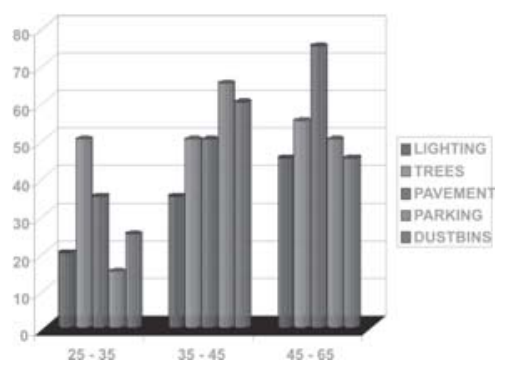



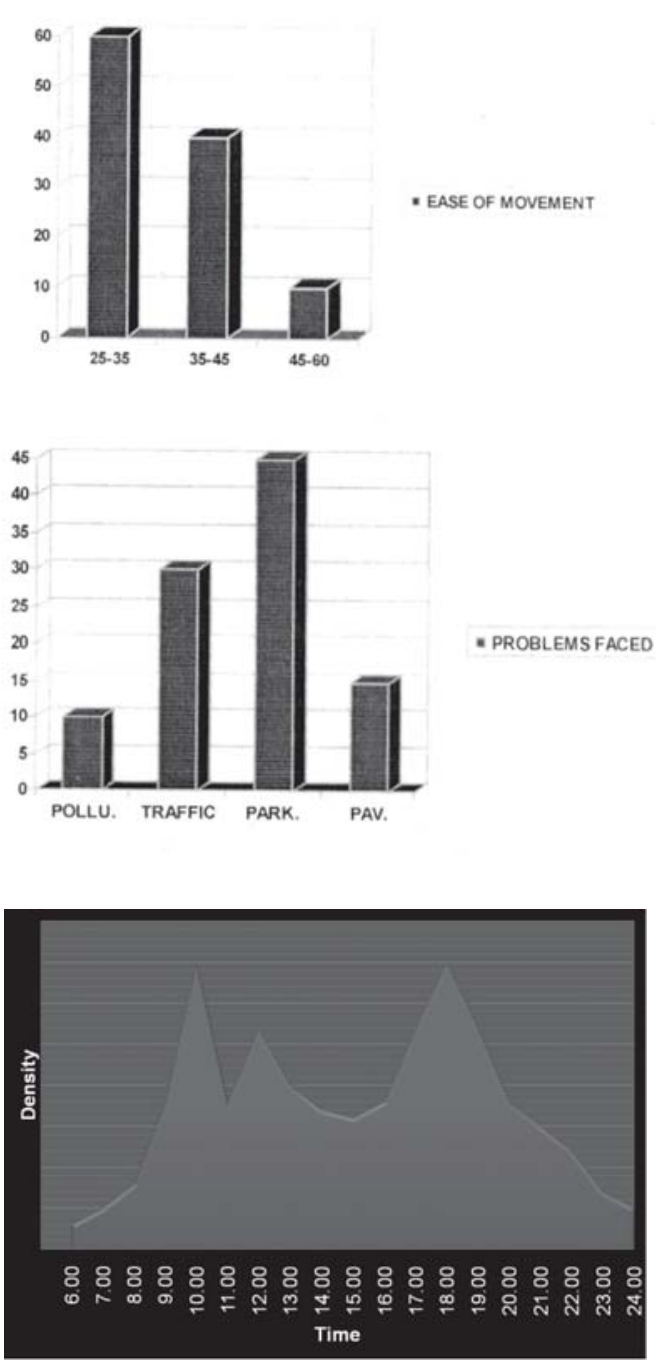

Traffic during a day

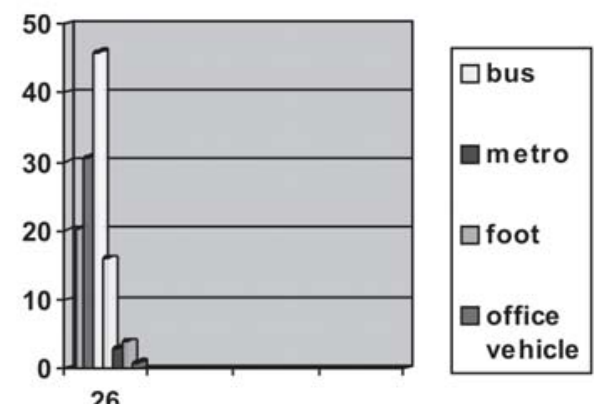

Mode of Transport

\section{CONCLUSION}

D The core and satellite city and the linear city are identical in overall area required as well as the size of built-up area and open land; the star has the same built-up area but needs 5,143 ha more open land than the other cities if the depth of its fingers is $1,200 \mathrm{~m}$. If the finger depth is increased to $2,400 \mathrm{~m}$ the star city's overall area becomes identical with that all the other city models.

D Distances between the edge of the built-up area the centre differ considerably as a result of the different geometry and fragmentation of the urban fabric; the $t$ values are achieved by the linear city $(1,200 \mathrm{~m}$ with depth of development 2,400 m) and the core city $(3,642 \mathrm{~m})$, the worst by the $\operatorname{star}(6,203 \mathrm{~m})$ with depth of development of the fingers $1,200 \mathrm{~m}$ ).

D However, when maximum distances between any point in the city and the edge of the open country are compared, the ranking order is rather different: the linear city is best $(1,200 \mathrm{~m})$, followed closely by the star and satellite city $(1,754 \mathrm{~m})$, and the core city has the largest distance $(3,642 \mathrm{~m})$.

D Despite the good scoring of the linear city, the picture changes when overall dimensions of the city areas are compared; the diameters of the core and satellite city and the galaxy of settlements are best $(9,404 \mathrm{~m})$, followed by the star $(12,406 \mathrm{~m})$ with a finger depth of $1,200 \mathrm{~m}$; with a finger depth of $2,400 \mathrm{~m}$ the star's diameter becomes identical to that of the core and satellite city.

D The linear city has a length of $17,363 \mathrm{~m}$, which clearly indicates that this form is not suitable for a large population.

\section{A. Sustainable Transport Development Agenda Aims At}

$\checkmark$ Strategic Thinking

$\checkmark$ Holistic Approach

$\checkmark$ Expert\&Non-ExpertKnowledge

$\checkmark$ Political Commitment

$\checkmark$ Social Responsiveness

$\checkmark$ Ethical Guideline

$\checkmark$ Participative Processes

$\checkmark$ Reflexive Institutions 


\section{REFERENCES}

1. Image of the City-Kevin Lynch

2. Good City Form -Kevin Lynch

3. Elements of Urban Form- George Banz

4. The Political Culture of Planning- J. Barry Cullingworth

5. Urban Space: Krier Rob

6. Cities and Space: Wingo

7. Various Town Planning Reviews/Journals

8. Design of Cities-Edmund Bacon

9. Ekistics-C.L.Doxiadis

10. Architecture of Towns and Cities-Paul.D.Spreiregen

11. Town Design-Frederic Gibberd

12. The Making of Cities- Walter Bor

13. The New Urbanism-Peter Katz

14. The Future of Cities-Andrew Blowers and Others

15. Urbanisation in Ancient India-Vijay Kumar Thakur
16. Case studied of the Urban Form of Islamic World

17. Metropolitan City Governance in India- Marina r. Pinto

18. Nagarlok-April June, 2004

19. Journal of American Planning Association- Spring 2004

20. A.K. Jain Emerging Vision towards Habitat Planning and Good Urban Governance

21. D.P. Tiwari, Challenges in Urban Planning for local bodies in India

22. Kulwant Singh, Trends And Issues In Decentralisation And Urban Governance In India.

23. Urvija Shukla Governance and New City Forms

24. Gerrit-Jan Knaap Measuring Patterns of Urban Development: New Intelligence for the War on Sprawl

25. Stephen Marshall: Defining the Dimensions of Urban Design

26. Designing the City -Hildebrand Frey 